\title{
Pengembangan Bentuk Lembar Kerja Siswa (LKS) untuk Aktivitas Kelas dan Laboratorium Berbasis Inkuiri Terbimbing pada Pokok Bahasan Laju Reaksi Vika Aumi $^{\# 1}$ Mawardi $^{\# 2}$ Rahadian Zainul $^{\# 3}$
}

Jurusan Kimia, Universitas Negeri Padang, Indonesia

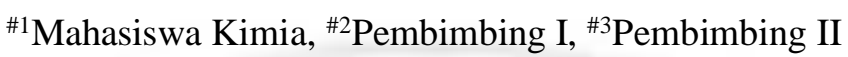

vika.aumegmail.com

mawardianwareyahoo.com

rahadianzmsiphdeyahoo.com

\begin{abstract}
Chemistry is a science that involves learning activities in the classroom and in the laboratory In curriculum 2013, requires students to be actively involved in the learning process. This study aims to develop student' worksheet for the classroom and laboratory activities-based guided inquiry on the subject rate of reaction, as well as reveal its validity and practicalities level. This type of research is educational design research (EDR) by uisng Plomp development model. Stages of development model is comprised of preliminary research, prototyping stage and the assessment phase. Student Worksheet developed validated by six validators ( 3 chemistry lecturers of FMIPA UNP and 3 high school chemistry teachers). Based on research, Student worksheets for the classroom and laboratory activities-based guided inquiry on the subject rate of reaction with the average value of the validity of $0.86,0.84$ practicalities value from teachers and students value the practicalities of 0.76 . Based on the results of this study concluded that the Student Worksheet for the classroom and laboratory activities-based guided inquiry can be developed to subject rate of reaction and Student Worksheet for the classroom and laboratory activities-based guided inquiry on the subject rate of reaction that has developed a very high validity category, practicality is very high from teachers, and high practicality from students.
\end{abstract}

Keywords: Student Worksheet based Guided Inquiry, rate of reaction, Plomp development model, validity and practicalities

\section{PENDAHULUAN}

Ilmu kimia merupakan ilmu yang mempelajari banyak hal yang bersifat abstrak dan kompleks ${ }^{[1]}$. Namun untuk memudahkan dalam mempelajarinya dapat digunakan pemodelan. Ilmu kimia juga merupakan pengetahuan laboratorium, artinya pembelajaran kimia tidak akan efektif tanpa adanya aktifitas laboratorium $^{[2]}$.

Ilmu kimia dapar digambarkan dalam tiga tingkat representasi kimia yaitu tingkat makroskopik, submikroskopik dan simbolik ${ }^{[10]}$. Kunci pokok dari pemecahan masalah terdapat pada saat merepresentasikan fenomena kimia pada tingkat submikroskopik. Pemahaman yang benar terhadap tiga tingkat representasi kimia akan menghasilkan konsepsi yang benar tentang kimia ${ }^{[1]}$.

Laju reaksi merupakan salah satu pokok bahasan dalam ilmu kimia. Pada laju reaksi terdapat konsep- konsep yang dalam pemahamannya membutuhkan tiga tingkatan representasi kimia. Laju reaksi merupakan pokok bahasan yang penting untuk dipelajari, karena laju reaksi merupakan materi prasyarat dalam mempelajari materi keseimbangan kimia.

Pembelajaran laju reaksi berdasarkan kurikulum 2013 dilakukan melalui pembelajaran di kelas dan di laboratorium dengan menggunakan pendekatan saintifik. Pendekatan saintifik merupakan pendekatan pembelajaran yang berorientasi atau berpusat pada siswa. Dalam pembelajaran dengan pendekatan saintifik siswa diharapkan dapat mengkonstruksi pengetahuannya sendiri. Namun, pembelajaran laju reaksi yang terjadi saat ini belum sepenuhnya terpusat kepada siswa sebagaimana tuntutan dari kurikulum 2013. Pembelajaran di laboratorium sebagian besar hanya digunakan untuk mengkonfirmasi konsep, bukan untuk menemukan 
konsep. Salah satu cara yang dapat dilakukan untuk mengatasi masalah tersebut adalah dengan menggunakan model pembelajaran yang tepat. Salah satu model pembelajaran yang sesuai dengan pendekatan saintifik adalah model pembelajaran inkuiri terbimbing

Model pembelajaran inkuiri terbimbing merupakan model yang membiasakan siswa mempelajari dan memecahkan masalah, berfikir kritis, berasumsi dan bertanggung jawab dalam mencapai pemahaman secara mandiri ${ }^{[3]}$. Model pembelajaran inkuiri terbimbing yang digunakan pada aktivitas pembelajaran di kelas terdiri dari 5 tahap yaitu, orientasi, eksplorasi, pembentukan konsep, aplikasi dan penutup ${ }^{[4]}$. Pada aktivitas kelas model yang dieksplorasi siswa berupa gambar, grafik, tabel serta persamaan. Sedangkan untuk aktivitas laboratorium, proses pembelajaran inkuiri terbimbing mengacu pada 3 tahap utama inkuiri terbimbing yaitu, eksplorasi, pembentukan konsep dan aplikasi ${ }^{[5]}$. Pembelajaran inkuiri terbimbing pada aktivitas laboratorium terdiri dari tiga fase yaitu pre$l a b$, the lab procedure dan post-lab ${ }^{[2]}$ Sedangkan untuk aktivitas laboratorium model yang digunakan berupa kegiatan praktikum dan gambar. Pelaksanaan pembelajaran akan berjalan dengan lancar dan efisien apabila menggunakan bahan ajar. Salah satu jenis bahan ajar yang dapat digunakan pada model pembelajaran inkuiri terbimbing adalah Lembar Kerja Siswa (LKS) ${ }^{[9]}$.

Berdasarkan hal tersebut dilakukan suatu penelitian pengembangan Lembar Kerja Siswa (LKS) untuk aktivitas kelas dan laboratorium berbasis inkuiri terbimbing pada pokok bahasan laju reaksi. Tujuan dari penelitian ini adalah untuk mengembangkan LKS untuk aktivitas kelas dan laboratorium berbasis inkuiri terbimbing pada pokok bahasan laju reaksi dan mengungkapkan tingkat validitas dan praktikalitas LKS yang dikembangkan.

\section{METODE PENELITIAN}

Jenis penelitian yang dilakukan adalah penelitian pengembangan pendidikan atau educational design research (EDR). Penelitian yang dilakukan menggunakan model pengembangan Plomp seperti yang dikemukakan oleh Tjeerd Plomp). Model Plomp terdiri dari 3 tahap, yaitu penelitian pendahuluan (preliminary research), pembuatan prototipe (prototyping stage) dan tahap penilaian (assessment phase ${ }^{[6]}$. Subjek penelitian ini adalah dosen jurusan kimia FMIPA UNP, guru kimia, dan siswa kelas XI SMA.

Pada tahap pertama, penelitian pendahuluan dilakukan analisis kebutuhan dan konteks, kajian literatur, mengembangkan kerangka konseptual dan teoritis untuk penelitian. Pada tahap kedua, pembuatan prototipe perancangan LKS yang meliputi: perumusan tujuan pembelajaran, merancang LKS, dan menyusun instrumen penelitian serta realisasi rancangan yang dihasilkan. Hasil realisasi rancangan ini disebut sebagai prototipe 1 .



Gambar 1. Skema tahapan pengembangan menggunakan model Plomp

Pada prototipe 1 selanjutnya dilakukan evaluasi diri sendiri (self evaluation). Evaluasi ini bertujuan untuk melihat kelengkapan isi dan spesifikasi desain LKS (prototipe 1). Apabila masih terdapat kekurangan, maka dilakukan revisi terhadap prototipe 1. LKS revisi dari evaluasi diri sendiri disebut sebagai prototipe 2 .

Pada prototipe 2 yang dihasilkan dilakukan validasi. validasi dilakukan dengan mengkonsultasikan prototipe 2 kepada validator, yaitu 3 orang dosen jurusan kimia FMIPA UNP dan 3 orang guru kimia SMA. Daftar nama validator dapat dilihat pada tabel 1 . 
Tabel 1. Daftar Nama Validator

\begin{tabular}{|c|l|c|}
\hline No. & \multicolumn{1}{|c|}{ Nama Validator } & Spesialisasi \\
\hline 1. & Drs. Amrin, M.Si & Kimia Analitik \\
\hline 2. & Dr. Mawardi, M.Si & Kimia Analitik \\
\hline 3. & Dr. Rahadian Z, M.Si & Kimia Fisik \\
\hline 4. & Yanti Sofia & $\begin{array}{c}\text { Guru Kimia } \\
\text { SMAN 1 Padang }\end{array}$ \\
\hline 5. & Maverdi Ayang Pituan & $\begin{array}{c}\text { Guru Kimia } \\
\text { SMAN 1 Padang }\end{array}$ \\
\hline 6. & Laksminawati Yunaz, ST & $\begin{array}{c}\text { Guru Kimia SMA } \\
\text { Pembangunan } \\
\text { Lab UNP }\end{array}$ \\
\hline
\end{tabular}

Pada prototipe 2 juga dilakukan Evaluasi satusatu (one-to-one evaluation). Evaluasi ini bertujuan untuk meminta masukkan mengenai produk yang dikembangkan melalui wawancara terhadap 3 orang siswa yang tingkat intelektual yang berbeda-beda. Subjek penelitian pada evaluasi satu-satu ini adalah 3 orang siswa kelas XI SMAN 1 Padang. Berdasarkan saran dan masukan dari validator serta evaluasi satusatu, dilakukan revisi terhadap prototipr 2. Hasil revisi prototipe 2 disebut sebagai prototipe 3 .

Pada prototipe 3 yang dihasilkan, dilakukan uji coba terhadap kelompok kecil (small group). Uji coba ini ber tujuan untuk melihat respon siswa terhadap LKS melalui lembar praktikalitas. Uji coba ini dilakukan terhadap 6 orang siswa kelas XI SMAN 1 Padang. Hasil uji coba digunakan untuk evaluasi dari prototipe 3 . Revisi terhadap prototipe 3 akan menghasilkan prototipe 4 .

Pada tahap ketiga, tahap penilaian dilakukan uji coba lapangan (field test) terhadap prototipe 4. Tujuan dari uji ini adalah untuk melihat praktikalitas dari LKS (pritotipe 4) dari segi siswa dan guru. Uji coba ditujukan kepada 30 orang siswa. Hasil analisis terhadap respon guru dan siswa dapat mengungkapkan tingkat praktikalitas dari LKS. Hasil evaluasi terhadap prototipe 4 akah menghasilkan prototipe akhir (final). Tahapan pengembangan menggunakan model pengembangan Plomp dapat dilihat pada gambar 1 .

Instrumen pengmpulan data yang digunakan dalam penelitian ini adalah lembar validasi dan angket (respon guru dan siswa). Lembar validasi digunakan untuk menilai bahan ajar dari segi komponen isi, komponen konstruk, komponen kebahasaan, dan komponen kegrafisan. Angket bertujuan untuk mengetahui tingkat praktikalitas pemakaian LKS pada pembelajaran.

Data yang diperoleh pada penelitian ini adalah data primer, yaitu data yang didapatkan langsung dari subjek penelitian. Data validitas dan praktikalitas yang diperoleh kemudian alan diolah menggunakan formula kappa cohen, sehingga akan didapatkan momen kappa ${ }^{[7]}$.

$$
\text { moment kappa }(k)=\frac{P_{0}-P e}{1-P e}
$$

Tabel 1.Kategori Keputusan berdasarkan Moment Kappa (k)

\begin{tabular}{cc}
\hline Interval & Kategori \\
\hline $\mathbf{0 , 8 1}-\mathbf{1 , 0 0}$ & sangat tinggi \\
$\mathbf{0 , 6 1}-\mathbf{0 , 8 0}$ & Tinggi \\
$\mathbf{0 , 4 1}-\mathbf{0 , 6 0}$ & Sedang \\
$\mathbf{0 , 2 1}-\mathbf{0 , 4 0}$ & Rendah \\
$\mathbf{0 , 0 1}-\mathbf{0 , 2 0}$ & sangat rendah \\
$<\mathbf{0 , 0 0}$ & tidak valid \\
\hline III. HASIL DAN PEMBAHASAN
\end{tabular}

\section{A. Hasil Penelitian}

Tahap penelitian pendahulan (preliminary research)

\section{a. Analisis kebutuhan}

Analisis kebutuhan bertujuan untuk menentukan masalah terkait tuntutan kurikulum terhadap pembelajaran di sekolah. Pada kurikulum 2013 pelaksanaan pembelajarannya berorientasi kepada siswa aktif. Siswa dituntut aktif dan mandiri dalam pembelajaran dan peran guru adalah sebagai fasilitator dan motivator.

Berdasarkan wawancara dapat disimpulkan bahwa masalah utama yang terjadi di sekolah terkait dengan bahan ajar yang digunakan selama ini kurang melibatkan siswa secara aktif dalam proses pembelajaran. Selain itu, bahan ajar yang digunakan hanya sebagian kecil saja yang memiliki tiga tingkat representasi kimia (makroskopik, submikroskopik dan simbolik). Oleh karena itu, dibutuhkan suatu bahan ajar yang dapat meningkatkan pemahaman konsep siswa dan tidak hanya digunakan untuk mengkonfirmasi konsep saja, dapat menarik minat belajar siswa, membuat siswa aktif serta memuat ketiga level representasi kimia (makroskopik, submikroskopik, dan simbolik). Salah satu bahan ajar tersebut adalah Lembar Kerja Siswa (LKS) aktivitas kelas dan laboratorium berbasis inkuiri terbimbing. Selain menentukan masalah, pada analisis kebutuhan juga dilakukan analisis kurikulum, yaitu menentukan indikator, tujuan pembelajaran serta materi terkait laju reaksi.

\section{b. Analisis konstruk}


Analisis konstruk bertujuan untuk mengidentifikasi suasana pembelajaran yang terjadi di sekolah. Pembelajaran laju reaksi dilakukan dengan dua aktivitas, yaitu aktivitas pembelajaran teori di kelas dan aktivitas praktikum di laboratorium. Namun, sebagian besar aktivitas praktikum di laboratorium dilakukan hanya untuk mengkonfirmasi konsep, bukan untuk penemuan konsep. Selain itu, proses pembelajaran yang dilakukan sebagian besar hanya menggunakan buku cetak saja, sedangkan pada kurikulum 2013 ini, siswa diharapkan dapat belajar dari berbagai sumber.

Tahap pembuatan prototipe (prototyping stage)

\section{a. Perancangan}

Pada tahap ini dilakukan perancangan LKS yang meliputi: perumusan tujuan pembelajaran, merancang LKS, dan menyusun instrumen penelitian serta realisasi rancangan yang dihasilkan. Berdasarkan indikator, dapat diturunkan 8 tujuan pembelajaran

LKS yang dirancang adalah LKS yang memuat aktivitas di kelas dan di laboratorium. Pembelajaran di kelas dirancang dengan menggunakan siklus belajar inkuiri terbimbing yaitu orientasi, eksplorasi, pembentukan konsep, penutup, dan aplikasi. Komponen LKS yang terdapat pada aktivitas kelas meliputi: judul, indikator, tujuan pembelajaran, informasi, model (berupa gambar, grafik, tabel, dll), pertanyaan kunci, latihan dan kesimpulan.

Sedangkan pembelajaran di laboratorium dirancang dengan menggunakan siklus inkuri terbimbing, yaitu: eksplorasi, pembentukan konsep dan aplikasi. Komponen LKS pada aktivitas laboratorium adalah judul praktikum, tujuan praktikum, informasi, keselamatan kerja, alat dan bahan, pertanyaan pre-lab, prosedur percobaan, hasil pengamatan, pertanyaan post-lab, pertanyaan aplikasi, dan kesimpulan. Percobaan yang dilakukan mengenai faktor-faktor yang mempengaruhi laju reaksi yaitu luas permukaan bidang sentuh, konsentrasi, suhu dan katalis. Pada tahap ini dilakukan spesifikasi tujuan pembelajaran dan perancangan LKS berbasis inkuiri terbimbing untuk aktivitas kelas dan laboratorium yang memuat model berupa gambar, grafik, atau tabel data dalam tiga level representasi (makroskopik, sub-mikroskopik dan simbolik), dan kegiatan laboratorium.

Dalam proses merancang desain awal LKS langkah yang dapat dilakukan diantaranya menentukan konsep yang akan ditemukan dalam aktivitas kelas dan konsep yang akan ditemukan pada aktivitas laboratorium bagi siswa. Selanjutnya dilakukan perancangan model sesuai multirepresentasi. Pembuatan model dilakukan berdasarkan acuan terhadap buku teks. Berdasarkan model yang dimuat dalam LKS, dibuatlah pertanyaan-pertanyaan kunci untuk membimbing siswa dalam menemukan konsep dengan mengamati dan menyelidiki model multirepresentasi yang diberikan.

\section{b. Realisasi}

Rancangan LKS yang sudah dibuat kemudian direalisasikan. Hasil realisasi rancangan ini disebut sebagai prototipe 1, yang dilakukan selanjutnya adalah:

1. Evaluasi diri sendiri (self evaluation) terhadap prototipe 1, bertujuan untuk melihat kelengkapan isi dan spesifikasi desain LKS (prototipe 1). Evaluasi ini dilakukan dengan menggunakan daftar cek (checklist) dari karakteristik atau spesifikasi desain Berdasarkan evaluasi diri sendiri, dapat diketahui bahwa masih terdapat kekurangan pada LKS, yaitu komponen daftar isi, soal evaluasi serta daftar pustaka belum terdapat pada LKS. Hasil revisi dari self evaluation adalah prototipe 2 .

2. Validasi dilakukan terhadap empat komponen, yaitu komponen isi, komponen penyajian, komponen kebahasaan dan komponen kegrafisan. Data penilaian dari validator terhadap LKS berbasis inkuiri terbimbing yang dikembangkan yang dapat dilihat pada Tabel 2.

Tabel 2. Data penilaian validitas LKS

\begin{tabular}{|c|c|c|c|}
\hline Aspek yang Dinilai & Jumlah Skor & $\mathrm{k}$ & $\begin{array}{c}\text { Kategori } \\
\text { kevalidan }\end{array}$ \\
\hline $\begin{array}{c}\text { Komponen } \\
\text { Kelayakan isi }\end{array}$ & 149 & 0,86 & Sangat Tinggi \\
\hline $\begin{array}{c}\text { Komponen } \\
\text { Kebahasaan }\end{array}$ & 63 & 0,85 & Sangat Tinggi \\
\hline $\begin{array}{c}\text { Komponen } \\
\text { Penyajian }\end{array}$ & 102 & 0,82 & Sangat Tinggi \\
\hline $\begin{array}{c}\text { Komponen } \\
\text { Kegrafisan }\end{array}$ & 87 & 0,90 & Sangat Tinggi \\
\hline Jumlah Skor Total & 401 & 0,86 & Sangat Tinggi \\
\hline
\end{tabular}

Hasil validasi dari keempat komponen penilaian, menunjukkan bahwa LKS yang dikembangkan memiliki tingkat validitas yang sangat tinggi, namun masih terdapat beberapa saran dari validator untuk perbaikan. 
3. Evaluasi satu-satu (one-to-one evaluation) menunjukkan bahwa LKS berbasis inkuiri terbimbing yang dikembangkan sudah dapat membantu siswa untuk memahami materi reaksi oksidasi-reduksi dan tatanama senyawa, memiliki desain gambar dan penampilan warna yang menarik. Namun terdapat beberapa hal yang disarrankan oleh siswa, yaitu agar identitas siswa dipisahkan dari cover serta jumlah soal latihan ditambah. Hasil evaluasi satu-satu dan saran validator pada tahap validasi digunakan untuk revisi LKS yang dikembangkan sehingga diperoleh prototipe 3 .

4. Uji coba kelompok kecil (small group or microevaluation) diujikan pada prototipe 3 . Uji ini bertujuan untuk mengetahui kepraktisan dari prototipe 3 yang telah dihasilkan. Hasil evaluasi kelompok kecil menunjukkan bahwa LKS sudah memiliki tingkat kepratikalitasan yang tinggi dengan momen kappa sebesar 0,68, namun pada LKS masih perlu dilakukan perbaikan. Oleh karena itu dilakukan revisi LKS sehimgga terbentuk prototipe 4 . Prototipe 4 inilah yang akan dicobakan dilapangan (field test)

\section{Tahap penilaian (assessment phase)}

Pada tahap ini dilakukan proses uji coba lapangan (field test). Uji coba ini ditujukan pada guru dan siswa dengan tujuan untuk melihat Praktikalitas LKS untuk aktivitas kelas dan laboratorium berbasis inkuiri terbimbing pada pokok bahasan laju reaksi. Hasil uji coba lapangan berupa data praktikalitas yang diperoleh melalui angket respon guru mata pelajaran kimia dan angket respon siswa. Hasil pengolahan data angket respon guru dan siswa dapat dilihat pada tabel 3 .

Tabel 3. Data praktikalitas LKS

\begin{tabular}{ccc}
\hline Data praktikalitas & $\begin{array}{c}\text { Momen } \\
\text { kappa }\end{array}$ & Kategori \\
\hline Angket respon guru & 0,84 & Sangat Tinggi \\
Angket respon siswa & 0,76 & Tinggi \\
\hline
\end{tabular}

Hasil pengolahan data angket respon guru dan siswa pada Tabel 3. menunjukkan bahwa LKS berbasis inkuiri terbimbing yang dikembangkan sudah memiliki praktikalitas yang sangat tinggi dari guru dan praktikalitas yang tinggi dari siswa.

\section{B. Pembahasan}

Proses pengembangan Lembar Kerja Siswa (LKS) untuk aktivitas kelas dan laboratorium berbasis inkuiri terbimbing pada pokok bahasan laju reaksi

Lembar Kerja Siswa (LKS) untuk aktivitas kelas dan laboratorium berbasis inkuiri terbimbing pada pokok bahasan laju reaksi dikembangkan sesuai dengan model pembelajaran inkuiri terbimbing. LKS yang dikembangkan memuat 2 aktivitas, yaitu aktivitas kelas dan aktivitas laboratorium.

Dalam mempelajari kimia, siswa tidak hanya harus mempelajari lebih tentang konsep dan prinsip ilmu-ilmu secara lisan (verbal), berulang-ulang, memperkenalkan rumus dan istilah yang diberikan secara verbal ${ }^{[8]}$ LKS yang dikembangkan dilengkapi dengan model yang dapat membantu siswa dalam membangun dan memahami konsep. Pada aktivitas kelas, model yang digunakan berupa gambar, grafik, tabel dan reaksi kimia. Pada aktivitas laboratorium, model yang digunakan berupa praktikum dan gambar. LKS yang dikembangkan sudah melalui beberapa tahapan uji, dan sudah mengalami banyak revisi. Uji dan revisi yang dilakukan bertujuan untuk menghasilkan LKS yang lebih baik.

Validitas dan praktikalitas Lembar Kerja Siswa (LKS) untuk aktivitas kelas dan laboratorium berbasis inkuiri terbimbing pada pokok bahasan laju reaksi

Uji validitas terhadap Lembar Kerja Siswa (LKS) untuk aktivitas kelas dan laboratorium berbasis inkuiri terbimbing pada pokok bahasan laju reaksi dilakukan oleh 6 orang validator, yaitu 3 orang validator dari dosen jurusan Kimia dan 3 orang validator dari guru kimia SMA di kota Padang. Hasil analisis lembar validasi keenam validator dengan menggunakan formula kappa cohen menunjukkan bahwa Lembar Kerja Siswa (LKS) untuk aktivitas kelas dan laboratorium berbasis inkuiri terbimbing pada pokok bahasan laju reaksi yang dikembangkan memiliki validitas yang dikategorikan sangat tinggi, hal ini ditunjukkan dengan nilai momen kappa sebesar 0,86 .

Uji validitas LKS dilakukan terhadap empat komponen, yaitu komponen isi, konstruk, kebahasaan dan kegrafisan. Komponen isi LKSl memiliki momen kappa sebesar 0,86 dengan kategori kevalidan sangat tinggi. Momen kappa pada komponen konstruk adalah 0,85 dengan kevalidan sangat tinggi. Hal ini menunjukkan bahwa penyusunan LKS sudah sistematis dan sesuai dengan 
langkah-langkah pembelajaran inkuiri terbimbing. Proses pembelajaran inkuiri terbimbing terdiri dari 5 tahap, yaitu orientasi, eksplorasi, pembentukan konsep, aplikasi dan penutup ${ }^{[4]}$. Sedangkan untuk percobaan di laboratorium terdapat 3 fase yaitu prelab, lab procedural dan post-lab ${ }^{[2]}$. Komponen kebahasaan LKS memiliki momen kappa sebesar 0,82 dengan kategori kevalidan sangat tinggi.

Berdasarkan hasil analisis dan paparan di atas, dapat disimpulkan bahwa secara keseluruhan, LKS untuk aktivitas kelas dan laboratorium berbasis inkuiri terbimbing pada pokok bahasan laju reaksi yang dikembangkan sudah valid dengan kategori sangat tinggi. Walaupun denikian, namun masih ada beberapa komponen yang harus diperbaiki sesuai dengan saran yang diberikan oleh validator, maka dilakukan revisi terhadap LKS untuk aktivitas kelas dan laboratorium berbasis inkuiri terbimbing pada materi laju reaksi yang dikembangkan untuk selanjutnya diujicobakan.

Kepraktisan LKS yang dikembangkan dilihat dari keterpakaian produk melalui uji coba lapangan. Kepraktisan LKS dinilai oleh guru kimia dan siswa SMA kelas XI. Penilaian praktikalitas oleh guru dan analisis yang telah dilakukan, diperoleh momen kappa sebesar 0,84 dengan kepraktisan sangat tinggi dan oleh siswa sebesar 0,76 dengan kepraktisan tinggi. Praktikalitas yang dinilai terdiri atas tiga komponen yaitu kemudahan penggunaan, efisiensi waktu pembelajaran dan manfaat.

Hal ini menunjukkan bahwa LKS untuk aktivitas kelas dan laboratorium berbasis inkuiri terbimbing pada pokok bahasan laju reaksi yang dikembangkan dapat digunakan dalam kegiatan pembelajaran di sekolah. Dengan demikian, LKS untuk aktivitas kelas dan laboratorium berbasis inkuiri terbimbing pada pokok bahasan laju reaksi sudah valid dan praktis. sangat tinggi, kepraktisan sangat tinggi oleh guru dan kepraktisan tinggi oleh siswa.

\section{UCAPAN TERIMAKASIH}

Penulis mengucapakan terimakasih kepada Bapak Drs. Amrin, M.Si, Ibu Dr. Latisma Dj, M.S, Ibu Dra. Syamsi Aini, Ph.D, serta semua pihak yang telah membantu dalam penyelesaian penelitian dan penyusunan artikel ini.

\section{DAFTAR RUJUKAN}

[1] Halim et al. 2013. Mental Model In Learning Chemical Bonding: A Preliminary study. Johor: Elsevier Ltd

[2] ACS. 2012. ACS Guidelines and Recommendations for the Teaching of High School Chemistry. Washington: American Chemical Society.

[3] Abidin, Yunus. 2014. Desain Sistem Pembelajaran: Dalam Konteks Kurikulum 2013. Bandung: Refika Aditama

[4] Hanson, D. 2005. Designing Process-Oriented Guided-Inquiry Activities. New York: Pasific Crest.

[5] College Board. 2012. AP $P^{\circledR}$ Chemistry Guided-Inquiry Experiments: Appliying the Science Practices (Teacher Manual). New York: The College Board

[6] Plomp, Tjeerd dkk. 2007. An Introduction to Educational Design Research. Netherland: SLO.

[7] Boslaugh, Sarah dan Paul A. W. (2008). Statistics in a Nutshell, a desktop quick reference. Beijing, Cambridge, Famham, Köln, Sebastopol, Taipei, Tokyo: O'reilly.

[8] Rahmiati, Sari dan Mawardi. 2016. "Teaching Materials Development of Student Work Sheet (SWS) Guided Inquiry Based on the Materials for Learning Rate of Chemical Reaction". Proceedings of Academics World $28^{\text {th }}$ International Conference, $28^{\text {th }}$ March 2016. Tokyo, Japan.

[9] Zainul, Rahadian. .2016. Disain, Metode Dan Penggunaan Software Pembelajaran Kimia Berbasis It Untuk Aktivitas Kelas dan Laboratorium Berbasis Inkuiri Terbimbing. Seminar Nasional Kimia FMIPA UNP. https://doi.org/10.31227/osf.io/psf5t

[10] Zainul, R., \& Jannah, A. R. 2017. Pengembangan Media Pembelajaran Asam Basa Menggunakan Aplikasi Android Berbasis Chemistry Triangle Kelas XI SMA/MA. Skripsi. FMIPA UNP. https://doi.org/10.31227/osf.io/muh8y

\section{SIMPULAN}

Berdasarkan penelitian yang telah dilakukan, dapat disimpulkan bahwa Lembar Kerja Siswa (LKS) untuk aktivitas kelas dan laboratorium berbasis inkuiri terbimbing dapat dikembangkan untuk bahasan laju reaksi, dan memiliki kategori kevalidan 


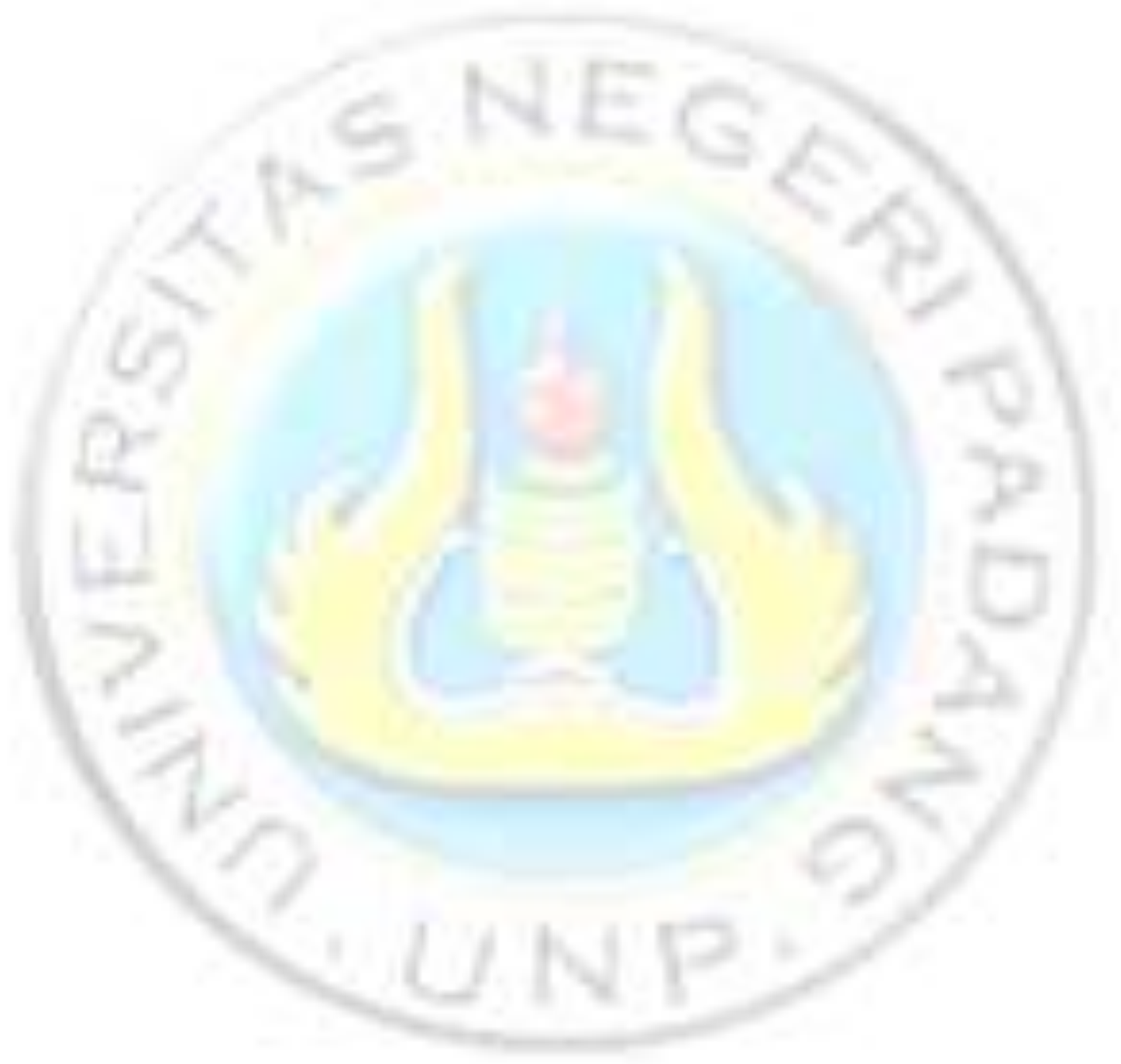

